\title{
Health effects, environmental impacts, and photochemical degradation of selected surfactants in water
}

\author{
Sarah Hatfield Venhuis and Mehrab Mehrvar ${ }^{\dagger}$ \\ Department of Chemical Engineering, Ryerson University, 350 Victoria Street, Toronto, Ontario, Canada M5B 2K3
}

\begin{abstract}
Surfactants are depended upon worldwide as cleaning agents. Their usage in such large quantities means that their waste and the potential for pollution are high. Many studies have been done over the last three decades encompassing treatment, alternatives to non-biodegradable surfactants, and the environmental impact. It has been found that although certain surfactants may not be directly toxic, when their concentrations are high in soil, they can act as agents to release toxic pollutants such as polychlorinated biphenyls (PCBs). The focus of this study is to review recent advances in the toxicology, the environmental fate, and the treatment of selected surfactants. In addition, photolytic and photocatalytic degradation of linear alkylbenzene sulfonate in water is presented.
\end{abstract}

\section{INTRODUCTION}

It is well known that surfactants pose a threat to the aquatic environment. Surfactants are used on a largescale basis worldwide in everyday household use to industrial cleaning and textile manufacturing. Tables 1 to 3 outline the annual consumption of three surfactants.

It is well documented that surfactants make up a large percentage of refractory chemical oxygen demand (COD) in municipal wastewater treatment and in traditional septic-tile bed system effluents. Other problems that are a result of surfactant pollution include the ability of surfactants to increase the solubility of other toxic organic compounds in soils and when adsorbed to sludge that can have a negative impact on sludge dewatering characteristics at municipal water treatment plants. Two suggestions for reducing surfactant pollution include dispensing only the quantity required of the major components for a particular wash cycle or using environmentally friendly detergents [7]. The objective of this paper is to study the photochemical treatment of surfactants in water as well as to study recent advances and development in the treatment of surfactants using advanced oxidation processes. Health effects, environmental impacts, and the treatment of linear alkylbenzene sulfonate (an anionic surfactant) and alkylphenol ethoxylates (a nonionic surfactant group) including their metabolic products are also discussed.

\section{FATE AND ENVIRONMENTAL IMPACTS OF SURFACTANTS}

2.1. Environmental concentrations of surfactants. Alkylphenol polyethoxylates are non-ionic

\footnotetext{
†E-mail: mmehrvar@ryerson.ca
}

surfactants used as detergents, emulsifiers, wetting agents, stabilizers, defoaming agents, intermediates in the synthesis of anionic surfactants, and institutional and industrial surface cleaners [8]. Alkylphenol polyethoxylates are also used in the preparation of phenolic resins, as heat stabilizers, in polymer production, and as antioxidants [9]. 55\% of alkylphenol polyethoxylates manufactured are used in industrial applications other than as cleaning products, 30\% are for industrial and institutional cleaning products, and $15 \%$ are manufactured for household cleaning products [9]. Alkylphenol polyethoxylates have been found in air $\left(0-81 \mathrm{ng} / \mathrm{m}^{3}\right)$, surface waters, sediment, and in wastewaters. Tables 4 and 5 outline the concentrations found in these environments.

Alkylphenol polyethoxylates and their metabolites are "ubiquitous in the environment" due to their widespread use and lack of adequate treatment [9]. Alkylphenol polyethoxylate pollution has been identified in localized areas close to the point of discharge of sewage treatment plant effluent [10]. A Dutch study of various surfactants in raw sewage, settled sewage, effluent and in primary removal gave the following results shown in Table 5.

Overall, the concentration in sewage treatment plant effluent depends on the treatment efficiency and plant design [9]. The 90th percentile surfactant concentrations 1 kilometre downstream of a sewage outfall were studied by using information obtained on release, removal in sewer, treatment efficiency, in stream removal and dilution in the Netherlands. For lower concentrations of the surfactant or soap, a higher removal rate has been observed [1]. It has been reported that maximum permissible concentrations (MPC) for Dutch surface waters are 250, 110, 400, and $27 \mu \mathrm{g} / \mathrm{L}$ for linear alkylbenzene sulfonate, alcohol ethoxylates, alcohol ether sulfates, and soap, respectively [12]. 
Table 1. Linear alkylbenzene sulfonate consumption.

\begin{tabular}{lcc}
\hline Area & $\begin{array}{c}\text { Consumption } \\
\text { Metric tonnes/year }\end{array}$ & Reference \\
\hline Netherlands & 13,550 & {$[1]$} \\
Western Europe & 320,000 & {$[2]$} \\
North America & 400,000 & {$[3]$} \\
United States & 415,000 & {$[4]$} \\
Worldwide & $1,500,000-2,000,000$ & {$[5,6]$} \\
\hline
\end{tabular}

Table 2. Alcohol ethoxylate sulfate consumption.

\begin{tabular}{lcc}
\hline Area & $\begin{array}{c}\text { Consumption } \\
\text { Metric tonnes/year }\end{array}$ & Reference \\
\hline Netherlands & 3587 & {$[1]$} \\
North America & 370,000 & {$[3]$} \\
United States & 322,000 & {$[4]$} \\
\hline
\end{tabular}

Table 3. Alcohol ethoxylate consumption.

\begin{tabular}{lcc}
\hline Area & $\begin{array}{c}\text { Consumption } \\
\text { Metric tonnes/year }\end{array}$ & Reference \\
\hline Netherlands & 9703 & {$[1]$} \\
North America & 256,000 & {$[3]$} \\
United States & 208,000 & {$[4]$} \\
\hline
\end{tabular}

2.2. Fate and environmental impacts of linear alkylbenzene sulfonate (LAS). Linear alkylbenzene sulfonate, the primary surfactant in liquid household detergents, has been found both in rivers that receive municipal effluents and in drinking water supplies. In wastewater treatment, more than $99 \%$ of LAS is removed while the remaining LAS is released into surface waters. Organisms living near sewage outfalls potentially can bioaccumulate LAS [13]. In Taiwan, less than $5 \%$ of the population's wastewater is treated. As a result, concentrations of $135 \mu \mathrm{g}$ LAS/L have been found in downstream from raw sewage outfalls in the LaoJie river [14]. As well, it has been documented that LAS makes up $0-488 \mathrm{mg} / \mathrm{kg}$ of the total dry weight of sewage sludge and may influence microbial activity of the soils. Another study reported a mean LAS concentration of $530 \mathrm{mg} / \mathrm{kg}$ and a maximum of $16000 \mathrm{mg} / \mathrm{kg}$ (dry weight) in the sewage sludge [15]. The short-term effects of the impact of LAS on agricultural soils that were amended by sewage sludge varied with LAS concentration and incubation time [6]. As well, a previous study showed that LAS has the potential to inhibit biological activity [5]. The data suggested that a terrestrial risk assessment based on short-term effects of LAS completely describes the potential risk when LAS contaminated sewage sludge is applied to agricultural land. LAS in concentrations greater than $40-60 \mathrm{mg} / \mathrm{kg}$ had toxic effects on reproduction and growth of soil invertebrates [15]. Earthworms and enchytracids were four times more sensitive to LAS than springtails and mites. LAS is rapidly mineralized (complete degrada- tion to $\mathrm{CO}_{2}$ and water) in the aerobic part of the sludgeamended soil [16]. The toxicity of LAS to the Collembolan (Folsomia fimetaria) and the earthworm (Aporrectodia caliginosa) was tested and it was concluded that neither the chemical characteristics of the LAS nor the type of soil have a large impact on toxicity [17]. It was also demonstrated that partial degradation of LAS was effective in reducing the toxicity to water fleas (Daphni magna) and fathead minnows (Pimphales promelus) [18]. Alternatively, other researchers found that LAS did not pose a risk to fauna, plants, and essential functions of agricultural soils as a result of regular sewage sludge application [19]. It has been shown that plant growth was stimulated by LAS biodegradation in sludge-amended soil [20]. A study of the migration of LAS in soils based on the effects of freeze-thaw and wet-dry cycles on the formation of macropores showed that LAS was more mobile when these macropores were present [21]. Studies have shown that LAS is toxic to anaerobic digestion processes. Inhibition of propionate and acetate biodegradation occurred in the presence of LAS [22]. A 50\% inhibition of acetate degradation was observed in the presence of $14 \mathrm{mg} / \mathrm{L}$ LAS. $27 \mathrm{mg} / \mathrm{L}$ LAS was sufficient to cause a $50 \%$ inhibition in propionate degradation [22]. The optimization of anaerobic processes is highly dependent on understanding how surfactants have an effect, especially in industrial wastewaters with high surfactant loadings, on the degradation of these organics.

LAS pollution can also be as a result of onsite sewage systems that are not functioning properly. LAS degradation exceeded 96\% for an onsite system that had been in operation for 25 years [3]. Although these results show that LAS is fully biodegradable in onsite sewage treatment systems, it is important to note that the functional operation varies widely due to installation, climate, and maintenance practices. It was concluded that the mechanisms of its removal were most likely due to the biodegradation and sorption.

\subsection{Fate and environmental impacts of alkylphe-} nol ethoxylates (APEOs). APEOs include nonylphenol ethoxylates with varying ethoxylate chain length. Entry into the environment is a result of anthropogenic activity since these compounds are not naturally produced. The majority of APEOs are introduced to the environment through wastewater treatment plant effluents in both the liquid and sludge forms and in pesticide applications [9]. These compounds have also been identified as a result of pollution from onsite systems [23]. One study demonstrated that more than $99 \%$ of APEOs were removed in an onsite system that had been in use for 25 years [3]. A model has been developed to predict the fate of alcohol ethoxylates and alcohol ethoxylate sulfates in onsite sewage treatment systems [24]. Other researchers concluded that APEOs degradation products in biosolids might cause a negative 
Table 4. Concentrations of alkylphenols and ethoxylates in various environmental compartments in the USA and Canada (NPE-nonylphenol ethoxylate; number stands for number of ethoxylate units; OP-octylphenol; NP-nonylphenol; STP-sewage treatment plant); LOD-limit of detection [9].

\begin{tabular}{|c|c|c|c|c|c|c|}
\hline $\begin{array}{l}\text { Location and } \\
\text { environmental } \\
\text { compartment }\end{array}$ & $\begin{array}{l}\text { Number of } \\
\text { Samples }\end{array}$ & $\begin{array}{l}\mathrm{NP} \\
(\mu \mathrm{g} / \mathrm{L} \text { or } \\
\mu \mathrm{g} / \mathrm{kg} \text { for } \\
\text { sediment })\end{array}$ & $\begin{array}{l}\text { NPE1 } \\
(\mu \mathrm{g} / \mathrm{L} \text { or } \\
\mu \mathrm{g} / \mathrm{kg} \text { for } \\
\text { sediment })\end{array}$ & $\begin{array}{l}\text { NPE2 } \\
(\mu \mathrm{g} / \mathrm{L} \text { or } \\
\mu \mathrm{g} / \mathrm{kg} \text { for } \\
\text { sediment })\end{array}$ & $\begin{array}{l}\text { NPE3 } \\
(\mu \mathrm{g} / \mathrm{L} \text { or } \\
\mu \mathrm{g} / \mathrm{kg} \text { for } \\
\text { sediment })\end{array}$ & $\begin{array}{l}\mathrm{OP} \\
(\mu \mathrm{g} / \mathrm{L} \text { or } \mu \mathrm{g} / \mathrm{kg} \\
\text { for sediment) }\end{array}$ \\
\hline \multicolumn{7}{|l|}{ Canada } \\
\hline STP Effluent & 8 & $0.8-15.1$ & & & & $0.12-1.7$ \\
\hline Surface Waters & 38 & $<$ LOD-0.92 & $<$ LOD-7.8 & $<$ LOD-10 & & $<$ LOD-0.084 \\
\hline Sediments & 9 & $0.1-72$ & $<$ LOD-38 & $<$ LOD-6 & & $<$ LOD-1.8 \\
\hline \multicolumn{7}{|l|}{ USA } \\
\hline \multirow[t]{3}{*}{ STP Effluent } & 6 & $0.18-15.9$ & & & $8.77-78.8$ & \\
\hline & 1 & 16 & 5.5 & 0.8 & & 0.15 \\
\hline & 6 & $0.171-37$ & & & $<$ LOD-332 & $<$ LOD-0.673 \\
\hline \multirow[t]{2}{*}{ Sediments } & 22 & $0.077-0.416$ & $0.056-0.326$ & $0.038-0.398$ & $0.026-0.328$ & $0.00156-0.007$ \\
\hline & 10 & $6.99-13,700$ & $26.4-13,300$ & $16.1-3580$ & & $<$ LOD-45 \\
\hline
\end{tabular}

Table 5. Average surfactant concentrations in raw, settled and treated sewage from seven Dutch sewage treatment plants (unless noted otherwise) of LAS-linear alkylbenzene sulfonate; AE-Alcohol ethoxylate; AES-alcohol ethoxylated sulfate. (Numbers in parentheses indicate number of plants where data was obtained) [11].

\begin{tabular}{llllll}
\hline Surfactant & $\begin{array}{l}\text { Concentration } \\
\text { in raw } \\
\text { sewage } \\
(\mathrm{mg} / \mathrm{L})\end{array}$ & $\begin{array}{l}\text { Concentration } \\
\text { in settled } \\
\text { sewage } \\
(\mathrm{mg} / \mathrm{L})\end{array}$ & $\begin{array}{l}\text { Concentration } \\
\text { in effluent }\end{array}$ & $\begin{array}{l}\text { Primary } \\
\text { removal }\end{array}$ & $\begin{array}{l}\text { Total } \\
\text { removal }\end{array}$ \\
\hline LAS & $5.2(6)$ & $3.7(5)$ & 39.1 & $20.3(4)$ & 99.1 \\
AE & 3.0 & $2.0(5)$ & 6.2 & 26.2 & 99.7 \\
AES & 3.2 & $1.5(5)$ & 6.6 & 29.5 & 99.7 \\
Soap & 28.1 & $9.8(5)$ & 1053 & $51.4(5)$ & 96.9 \\
\hline
\end{tabular}

environmental impact in the U.S.A. as a result of widespread biosolids application [25]. APEOs are of environmental concern because their biodegradation leads to more toxic and persistent compounds that may have estrogenic activity [25-28]. Toxicological properties are influenced by the number of ethoxylate (EO) units. APEOs with short EO chains (less than four) are lipophilic and may lead to bioaccumulation/bioconcentration and those with greater than ten EO units are hydrophilic. Generally, the toxicity of APEOs increases as the number of EO units decreases [8]. Ekelund et al. [29] studied the bioaccumulation of 4-nonylphenol (a primary metabolite of NPnEOs) in marine animals and found that bioconcentration factors exceeded those previously published for fish and mussels. The bioconcentration factor for fish was determined to be 1300 (5 times greater than published values) and 3400 for mussels (340 times greater than published values). It was determined that the lethal thresholds for alkylphenols in aquatic fauna decrease with increasing $\mathrm{K}_{\mathrm{ow}}$ and the bioconcentration factor increases with increasing $\mathrm{K}_{\mathrm{ow}}$ in salmon [30]. Nonylphenol ethoxylates (NPEOs) and their primary degradation products were measured in sediments in the Straight of Georgia, B.C. near a municipal outfall. It was calculated that 30 tonnes of NPnEO (nonylphenol ethoxylate with $\mathrm{n}$ ethoxylate groups) is in the Fraser River Delta sediment while nearly 170 tonnes in the entire Straight of Georgia [31]. Various alkylphenol ethoxylate metabolites in Jamaica Bay, Long Island, New York were found with concentrations of $0.05-30 \mu \mathrm{g} / \mathrm{g}$ of NPnEO and 0.007-0.040 $\mu \mathrm{g} / \mathrm{g}$ of octylphenol ethoxylate metabolites in sediment [32]. It has been reported that some of the degradation products of NPEOs are not readily biodegradable under anaerobic condition [33]. A study by Hawrelak et al. [34] on the fate of alkylphenol ethoxylate primary degradation products in paper sludge spread onto farmers' fields showed that the concentration decreased by $84 \%$ over a 14 -week period. An indication of recalcitrant nonylphenol isomers was observed but it was concluded that more research should be done to assess the risk of APEOs degradation products in these sludges used as soil amendments.

Water treatment processes available to municipal wastewater treatment plants are not always suitable for the removal of surfactants at low concentrations. The treatment of surfactants at the source of pollution has many advantages including higher concentrations 
and the availability of more specialized treatment techniques such as advanced oxidation processes.

2.4. Influential factors in surfactant toxicity. In the literature, there are many conflicting studies as to the toxicity of linear alkylbenzene sulfonates in the aquatic environment. Many ecotoxicological studies have been conducted under laboratory conditions and do not sufficiently represent the varying water conditions in the water column. The main pathways responsible for LAS removal in the natural environment are biodegradation, adsorption, and precipitation. A study of the influence of $\mathrm{Ca}^{2+}$ to the toxicity of LAS on algae (D. magna) showed that the toxicity of LAS increased with alkyl chain length and an increase in water hardness. Concentrations of LAS ranged from $33-335 \mathrm{mg} / \mathrm{L}$ and water hardness (as $\mathrm{CaCO}_{3}$ ) was varied from $200-2000 \mathrm{mg} / \mathrm{L}$. Water hardness was found to stress D. magna, thereby, increasing LAS toxicity [35]. This is just one water parameter that varies widely in the environment. The results of this study indicated that controlled laboratory toxicological tests were not a suitable indication of toxicity in the aquatic environment due to these varying parameters. The relationship between interfacial properties and toxicity of several surfactants (including octyl-, dodecyl-, tetradecyl-, hexadecyl-trimethylammonium chloride, octyl- and decyl-dimethyl-2-hyrdroxy ethyl ammonium chloride, and LAS) on an immobilized artificial membrane was reviewed. The surfactant toxicity was primarily a function of the ability of the surfactant to adsorb and penetrate the cell membrane of aquatic organisms [36]. The structure-activity relationship for both acute and chronic toxicity of a variety of alcohol ether sulfates on Ceriodaphnia dubia has been investigated [37]. Acute toxicity was found to increase with alkyl chain length and decrease with an increasing number of ethoxylate units. Chronic toxicity tests were done using Brachionus calyciflorus. Chronic toxicity was found to be related to the percentage of the molecular surface associated with atoms possessing partial negative charges and with increasing the length of the ethoxylate chain.

The bioconcentration of alcohol ethoxylates in fathead minnows (Pimphales promelas) was dependent on alkyl and ethoxylate chain lengths [13]. The bioconcentration factor ranged from less than 5 to $1660 \mathrm{~L} / \mathrm{kg} /$ day. Studies of the estrogenic potency of alkylphenol ethoxylates and their metabolites on the Japanese Medaka fish found that the environmental concentrations of nonylphenol ethoxylates (NPEO1 and NPEO2) were not within the range of estrogenic activity [38]. NPEOs are metabolized in sewage treatment to 4-nonylphenol, 4-nonylphenoxyacetic acids, 4-nonylphenoldiethoxylate, and all are known to have estrogenic effects. The metabolites escape treatment and were detected in sewage treatment plant effluents [39]. Korner et al. [40] tested the estrogenicity of sewage treatment plant effluents and concluded that these effluents were the major sources of estrogenic substances in the environment. Sewage treatment plant (STP) outfalls are a perpetual source of these types of compounds. The presence of LAS in the environment close to sewage treatment plant outfalls was reviewed [41]. The concentration of LAS in sewage treatment plant effluent was in the range of $0.02-1.0 \mathrm{mg} / \mathrm{L}$ that was in the range reported to have a physiological impact on marine life. It was also reported that LAS can damage fish gills, cause excess mucus secretion, decrease respiration in the common goby, cause reduced settling rate, and change swimming patterns in blue mussel larvae. LAS was found to disrupt the ionic homeostasis of epithelial cells (these cells form the outermost barrier between the organism and the environment). The biotransformation of octaethylene glycol monotridecyl ether in fathead minnows played an important role in reducing bioconcentration potential of this surfactant [42]. A review of the acute effects of LAS on freshwater plankton and freshwater organisms (including bacteria to crustaceans) in field conditions revealed that LAS has a negative impact on the survival of heterotrophic nanoflagellates and ciliates at very low concentrations. The no-effect concentration was found to be lower in field tests than for similar organisms tested under laboratory conditions [43]. Predicted no effect concentrations (PNEC) are often used in environmental risk assessment. PNEC values vary widely for the same surfactant. Table 6 shows some PNECs for common surfactants.

A method for the application of risk assessment employing ratios of predicted environmental concentrations (PECs) and predicted no-effect concentrations (PNECs) to mixtures of surfactants and their metabolites was proposed [45]. The two main factors influencing risk assessment of the chemical in question are consideration of metabolites and/or their number [45]. Feijtel et al. [46] studied the predictive exposure modeling and concluded that to understand the fate of chemicals in the environment, it is important to remember these models do not fully represent the real world scenario although they can provide important statistical distributions of concentrations.

\section{SURFACTANT TREATMENT}

In the following section, the biodegradation of selected surfactants is discussed. In addition, photolytic and photocatalytic treatment of LAS in water is presented. For comparison, its treatment using other advanced oxidation processes is also discussed.

3.1. Biodegradation of surfactants. Biodegradability of organic pollutants is a desired property because of the relative ease of removal from waste 
Table 6. Predicted no-effect concentrations $(\mu \mathrm{g} / \mathrm{L})$; no observed effect concentrations (NOECs) and uncertainty factors for linear alkylbenzene sulfonate (LAS), alcohol ethoxylate (AE), alcohol ethoxylated sulfates (AES), and soap [44]. $\mathrm{C}_{\mathrm{x}}$ and $\mathrm{EO}_{\mathrm{y}}$ represent the average number of carbons and ethoxylate groups, respectively.

\begin{tabular}{lcccc}
\hline Surfactant & $\begin{array}{c}\text { PNEC based on single } \\
\text { species data }\end{array}$ & Range of field NOECs & Final PNEC & Uncertainty factor \\
\hline LAS $\left(C_{11.6}\right)$ & 320 & $250-500$ & 250 & 2 \\
AE $\left(C_{13.3} \mathrm{EO}_{18.2}\right)$ & 110 & $42-380$ & 110 & 5 \\
AES $\left(C_{12.5} \mathrm{EO}_{3.4}\right)$ & 400 & $190-3700$ & 400 & 5 \\
Soap & 27 & N/A & 27 & 10 \\
\hline
\end{tabular}

streams. Toxicity can be reduced or eliminated by biodegradation. Often, biological organisms can completely mineralize pollutants, producing carbon dioxide and water. In the following, the biodegradability of selected surfactants is discussed.

\subsubsection{Biodegradation of alkylphenol ethoxylates} (APEOs)

Jones and Westmoreland [47] conducted a study of nonylphenol ethoxylate degradation during sludge composting. The NPEO contaminated water was a result of washing of raw wool. This wash water typically is ten times more concentrated than the sewage. Usually, this wash water is treated using a chemical flocculation process and the sludge ends up with all of the surfactants from the detergent. This sludge was composted and it was shown that 14 weeks were sufficient to reduce the NPEO concentration by more than $96 \%$. Biodegradation of branched NPEOs showed that there was no significant difference between the biodegradability of NPEOs containing 8 to 30 ethoxylate groups [48]. It was also demonstrated that the removal of NPEO was greater than $90 \%$ in activated sludge processes with no prior acclimatization, i.e., operating under plant conditions [48].

The biodegradation of NPEOs and LAS (among other organic compounds) in sludge-amended soils was also studied [16, 49]. It was concluded that nonylphenol ethoxylates are mineralized in aerobic soil compartments [16]. It was also determined that as the concentration of NPEO (2 ethoxylate groups) was increased in sludge amended soil, the relative maximum mineralization rate decreased and resulted in an increase in lag times [49]. Biodegradation of alkylphenol ethoxylates (APEOs), alkyl ethoxylate sulfates (AESs), LAS, and primary metabolites in activated sludge treatment was also reviewed [4]. Alcohol ethoxylates (AE) and alcohol ethoxylate sulfates (AES) were removed with an efficiency of $98 \%$ and $97 \%$, respectively. Trickling filter treatment resulted in removal efficiencies for AE, AES and LAS to be $79-99.7 \%, 69.7-98.2 \%$, and $>99 \%$, respectively. AE removal during activated sludge treatment was reported at $>99 \%$ based on measured levels in the influent sewage and the treated effluent [50]. It was estimated that biodegradation was responsible for greater than $98.7 \%$ of the removal and the remainder adsorbed to the biomass. During winter operation, the biodegradation was responsible for greater than $97.2 \%$ of AE removal [50]. It was suggested that the alkyl chain length of alcohol polyethoxylates controlled the biodegradability rates and pathways [51]. The halflives of APEOs in acclimated sewage treatment plant sludges for ultimate biodegradation were one to four weeks [52]. Anaerobic degradation of alcohol sulfates was dependent on the surfactant to biomass ratios. Low surfactant to biomass ratio was important for efficient biodegradation. In addition, processes that result in acidification of the wastewater prior to anaerobic treatment improve degradation and allow for a higher surfactant to biomass ration without causing inhibition [53].

Biodegradation of alcohol ethoxylates from in-situ surfactant washing in soil by native soil microbes was also studied [54]. In-situ surfactant washing is a process for cleaning contaminated soil and ground water systems. For example, a site of soil contaminated with polychlorinated biphenyls (PCBs) can be injected with a surfactant solution to enhance the mobility of the PCBs and, therefore, the biodegradation. This ultimately leaves the surfactant in the soil. The study was conducted in order to assess the ability of native soil microbes to degrade the surfactant. It was found that alcohol ethoxylate is readily biodegradable by indigenous groundwater and soil microbes under laboratory conditions. The rate of surfactant degradation was enhanced by adding nutrients including nitrogen, phosphorus, and oxygen.

\subsubsection{Biodegradation of linear alkylbenzene sulfonate (LAS)}

The importance of sludge adaptation and mass transfer in the biodegradation process of LAS in activated sludge treatment was studied [55]. A model was developed to analyze the effects of adsorption and biodegradation kinetics on the fate of LAS in batch experiments with activated sludge adapted to different initial LAS concentrations. It was shown that in batch experiments, the mass transfer kinetics were sufficiently slow so that equilibrium was not reached and, therefore, the long-term biodegradation of LAS was limited by the 
increasing availability of LAS from the unavailable LAS over time. LAS removal during activated sludge treatment was greater than $99 \%$ while in a trickling filter was 72.2-98.6\% [4]. A pilot scale trickling filter was built to test a model for chemical fate in trickling filters. LAS removal was between 19-58\% under various operating conditions. The experimental data obtained was successfully fitted to the model within a specified range of influent LAS concentrations [56]. A study of the biodegradation of LAS in sewage-contaminated groundwater over a range of dissolved oxygen concentrations concluded that the rate of biodegradation increased with increasing alkyl chain length [57]. Removal rates were found to be two to three times higher in laboratory experiments than those in field tests. Doi et al. [58] investigated the sorption and biodegradability of LAS in three soil types below an onsite sewage system drain field. It was concluded that the rate of ultimate biodegradation of LAS decreased with increasing distance vertically below the surface of the ground. Percent mineralization of LAS was found to be $49.8 \%$ and $83.4 \%$ during test periods of 45 or 59 days, respectively. The applicability of a model developed to predict the fate and transport of surfactants in onsite wastewater treatment systems was reviewed. The model takes into account the adsorption and biodegradation on the transport of surfactants through the treatment system. It was found that the model under-predicted the LAS concentrations in groundwater downgradient from the disposal field. This is a result of anoxic conditions in the groundwater beneath the disposal field. It was also determined that the biodegradation of LAS was faster under fully oxygenated laboratory conditions than that of in the field [24]. The primary degradation of LAS in soil columns under water-saturated conditions was close to $100 \%$ while mineralization only occurred up to $9 \%$ [59].

\subsubsection{Biodegradation of ditallowdimethyl ammonium chloride (DTDMAC)}

The biodegradation of ditallowdimethyl ammonium chloride, a cationic surfactant by activated sludge has been studied [60]. DTDMAC is commonly used as a fabric-softening agent. The biodegradation of DTDMAC was determined in semi-batch activated sludge reactors. It was found that extended periods of aeration enhanced degradation rates. Although metabolites of DTDMAC were observed, they did not persist in the sludge. It was concluded that DTDMAC removal was a result of sorption, precipitation, and biodegradation mechanisms.

\subsection{Treatment of surfactants using various ad- vanced oxidation technologies and separation tech- niques. In this section, the treatment of selected sur- factants including alkylphenol ethoxylates (APEOs), al- cohol ethoxylates (AEs), and linear alkylbenzene sul-}

fonate (LAS) by advanced oxidation processes including $\mathrm{TiO}_{2} / \mathrm{UV}$, wet air oxidation, sonochemical degradation, foam fractionation, and electrochemically generated coagulant treatment is discussed.

\subsubsection{Treatment of surfactants with $\mathrm{TiO}_{2}$ combined with ultraviolet light (UV)}

In the last 20 years, the potential for usage of photocatalysts for organic pollutant destruction has been realized [61-68]. An ideal photocatalyst is chemically and biologically inert, easily recovered, and reusable. Titanium dioxide fits this profile and, hence, has been tested extensively in the treatment of a wide variety of organic contaminants.

The treatment of alcohol ethoxylates and nonylphenol ethoxylates in batch reactors was investigated [72]. Experimental conditions were as follows: $0.1 \% \mathrm{w} / \mathrm{v} \mathrm{TiO}$ catalyst, $2000 \mathrm{mg} / \mathrm{L}$ surfactant, and irradiation with a $400 \mathrm{~W}$ black light lamp. It was found that NPEO more easily degraded than $\mathrm{AE}$. $\mathrm{NP}_{\mathrm{n}} \mathrm{EO}$ (where $\mathrm{n}=2,5$ or 12) degradation in a batch reactor with Degussa P25 $\mathrm{TiO}_{2}$ and a $1500 \mathrm{~W}$ UV lamp in an $\mathrm{NP}_{n}$ EO solution with a concentration of $0.1 \mathrm{mM}$ was monitored by measuring $\mathrm{CO}_{2}$ evolution, dissolved organic carbon, and particulate organic carbon [70]. The reaction pathway involved a hydroxyl radical attack on the ethoxylate chain and on the benzene ring. The rate of reaction was dependent on adsorption of the surfactant to the titanium dioxide surface. Horikoshi et al. [71] studied the degradation of NPEO in a cylindrical reactor where titanium dioxide was immobilized on a fiberglass cloth. The photocatalytic degradation of sodium dodecylbenzene sulfonate (SDS), a linear alkylbenzene sulfonate with 12 carbon atoms in the alkyl chain, was investigated [72]. The degradation of LAS using Degussa P25 $\mathrm{TiO}_{2}$ combined with UV light at $365 \mathrm{~nm}$ was tested in batch mode. The setup included the UV lamp outside of the reactor placed symmetrically over top of the $500 \mathrm{~mL}$ Pyrex reactor. Various optimization parameters were tested including $\mathrm{pH}$, temperature, SDS and $\mathrm{TiO}_{2}$ concentration. SDS concentrations tested were in the range of $4.4-13.8 \mathrm{mg} / \mathrm{L}$ and $\mathrm{TiO}_{2}$ concentrations from $5-32 \mathrm{mg} / \mathrm{L}$. It was found that the optimum $\mathrm{pH}$ was 3 . As the temperature increased (up to $45^{\circ} \mathrm{C}$ ), the rate increased. The optimum $\mathrm{TiO}_{2}$ concentration was $8 \mathrm{mg} / \mathrm{L}$ for a $10.8 \mathrm{mg} / \mathrm{L}$ SDS solution. The photocatalytic degradation of SDS under similar conditions has also been studied [64]. The concentrations used were 0.01 and $0.1 \mathrm{mM}(34.8$ and $348 \mathrm{mg} / \mathrm{L})$ and $2.0 \mathrm{~g} / \mathrm{L}$ Degussa P25 $\mathrm{TiO}_{2}$. Based on the results obtained of intermediate compounds formed during degradation, mechanisms for SDS degradation were proposed. The first proposed mechanism involved radical attack of the aromatic ring. The second mechanism proposed involves radical attack to the alkyl chain. Photocatalytic degradation rates of two compounds, sodium benzene 
sulfonate (BS) and sodium dodecylsulfate (DS) were compared to the degradation of SDS to determine how the degradation mechanism occurs. Studies of intermediate compounds led to the conclusion that the aromatic and alkyl groups competitively adsorb to the titanium dioxide surface and degrade. The rate influencing steps for degradation of SDS were suggested by Hidaka et al. [64] as follows:

1. surfactant adsorption on $\mathrm{TiO}_{2}$ surface,

2. electron-hole pair formation or radical formation,

3. rate limiting steps included ring opening, peroxide, carboxylic acid, or aldehyde formation,

4. complete mineralization to $\mathrm{H}_{2} \mathrm{O}$ and $\mathrm{CO}_{2}$.

In our own research, the degradation of a commercial LAS containing LAS homologues with alkyl chain lengths varying from 10-14 carbon atoms was investigated. The commercial name of this product is Biosoft D40 and is manufactured by the Stepan Company (Northfield, Illinois, USA). Degradation was achieved using $\mathrm{H}_{2} \mathrm{O}_{2}$ combined with UV light at $254 \mathrm{~nm}$, Degussa $\mathrm{P}_{2} 5 \mathrm{TiO}_{2} / \mathrm{UV}$ at $365 \mathrm{~nm}$, and UV alone at $254 \mathrm{~nm}$. For the photocatalytic experiments, Phillips PLS 9W/10/UVA (Microlites Scientific) $365 \mathrm{~nm}$ lamps were used as the light source. For the photolysis experiments, a Phillips PLS TUV/PL-59 W with a nominal wavelength of $254 \mathrm{~nm}$ was used. All experiments were completed in 1-litre batches in $1.4 \mathrm{~L}$ beakers. During the experiments, the beakers were completely covered with aluminum foil to reflect light back into the reaction mixture. The reaction solutions were sufficiently stirred to minimize the mass transfer limitation of oxygen transfer to the liquid. The LAS concentration used in all experiments was approximately $152 \mathrm{mg} / \mathrm{L}$ and was analyzed using the MBAS (methylene blue active substances) according to the Standard Methods for the Examination of Water and Wastewater [73]. A series of experiments (repeated in triplicate) were completed to determine the optimum concentration of $\mathrm{TiO}_{2}$ for degradation of Biosoft D40. Our results indicate that $3.0 \mathrm{~g}$ Degussa $\mathrm{P} 25 \mathrm{TiO}_{2}$ is optimum for the degradation of Biosoft D40 for the experimental conditions. Initial rates were uses as the optimization parameter for all experiments. The optimum LAS degradation was found at $3.0 \mathrm{~g} / \mathrm{L} \mathrm{TiO}_{2}$ at an initial rate of $1.7 \mathrm{mg} \mathrm{LAS} / \mathrm{L}$ minute. Above $3.0 \mathrm{~g} \mathrm{TiO}_{2}$, the degradation rate decreases as a result of the light blocking effect of the additional titanium dioxide. Figure 1 illustrates the results of the $\mathrm{TiO}_{2}$ optimization experiments in terms of the initial rate of reaction.

Another series of LAS degradation experiments were carried out to determine the optimum concentration of $\mathrm{H}_{2} \mathrm{O}_{2}$ required for the destruction of the LAS compound. The $1 \mathrm{~L}$ stirred batches were irradiated with UV light at $254 \mathrm{~nm}$ for a period of 90 minutes. As in

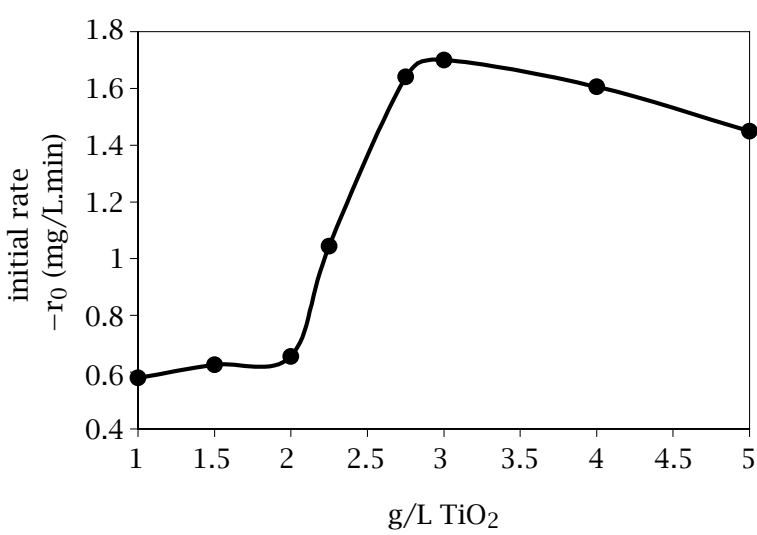

Figure 1. Optimization of $\mathrm{TiO}_{2}$ Concentration. Treatment of $L A S$ with $\mathrm{TiO}_{2}-U V_{365} \mathrm{~nm}$. Each data point on this graph represent the averages of the initial rate of three trials at each $\mathrm{TiO}_{2}$ concentration. $\mathrm{C}_{0}=152 \mathrm{mg} / \mathrm{L}$ LAS.

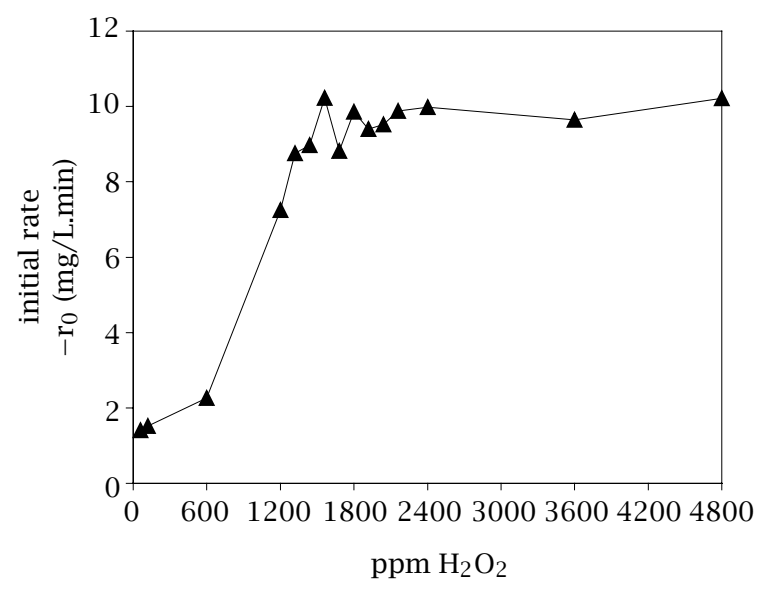

Figure 2. Optimization of $\mathrm{H}_{2} \mathrm{O}_{2}$ Concentration; Treatment of LAS with $\mathrm{H}_{2} \mathrm{O}_{2}-U V_{254} \mathrm{~nm}$. Each data point on this graph is the average of three trials at each hydrogen peroxide concentration. $\mathrm{C}_{\mathrm{O}}=152 \mathrm{mg} / \mathrm{L} \mathrm{LAS}$.

the $\mathrm{TiO}_{2}$ experiments, the initial rate was used as the optimization parameter. All hydrogen peroxide experiments were carried out in triplicates. A stock $\mathrm{H}_{2} \mathrm{O}_{2}(50 \%$ $\mathrm{w} / \mathrm{v}$ ) was used and the required amount was added immediately prior to turning on the UV lamp (254 nm). The optimum concentration of $\mathrm{H}_{2} \mathrm{O}_{2}$ was found to be $1560 \mathrm{ppm}$. A reaction time of less than 5 minutes was required for the destruction of the initial LAS compound. At the optimum concentration of hydrogen peroxide, the initial rate was $10.2 \mathrm{mg}$ LAS/L.min. There was some variability in the initial rates. It was suspected that this was a result of active species still present after taking the sample. Every effort was made to analyze samples as quickly as possible. Figure 2 shows the results of these experiments.

Figure 3 shows that UV light at $254 \mathrm{~nm}$ is successful in degrading LAS although it is not an efficient 


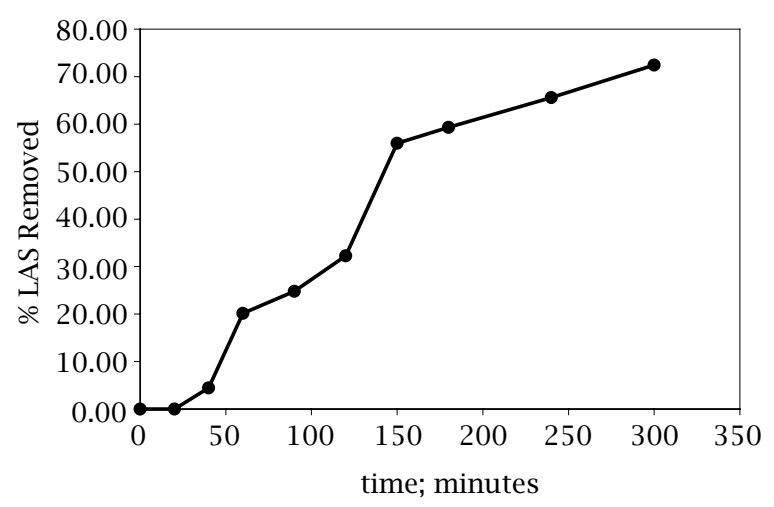

Figure 3. Degradation of LAS with UV-254 nm. $\mathrm{C}_{\mathrm{o}}=138$ mg LAS/L. No $\mathrm{TiO}_{2}$ or $\mathrm{H}_{2} \mathrm{O}_{2}$ was present in the system.

process since it takes 5 hours to degrade approximately $80 \%$ of the initial compound. The use of a high-energy lamp as the means for degradation is not cost effective as a result of the time and energy required. Of the advanced oxidation processes tested, hydrogen peroxide combined with UV light at $254 \mathrm{~nm}$ was the most effective method based on the calculated initial rates for the destruction of the initial compound LAS.

\subsubsection{Wet air oxidation of surfactants}

In a study of the applicability of wet air oxidation (WAO) for various organic pollutants, the basics of this process have been outlined [74]. WAO is suitable for the treatment of organic or inorganic pollutants dissolved in water. WAO is dependent on high temperatures and pressures operating in the range of $174-320^{\circ} \mathrm{C}$ and $2.17-$ 20.7 MPa, respectively. At high enough temperatures and pressures, the solubility of oxygen increases and provides the driving force for oxidation. The source of oxygen was either compressed air or pure oxygen. The high pressures are required to keep the water in a liquid state. WAO provides the same oxidative ability as flame combustion but at much lower temperatures. Mantzavinos et al. [75] studied the WAO of LAS and its effects on the biodegradation of LAS. The experiments were semi-batch with $1000 \mathrm{mg} / \mathrm{L}$ LAS at $473 \mathrm{~K}, \mathrm{O}_{2}$ partial pressure of $1.3 \mathrm{MPa}$ and a reaction time of 40 to 390 minutes. It was found that although LAS was easily oxidized by WAO to compounds that do not act as surfactants, unoxidized LAS was more readily biodegradable than that of the treated LAS. Biodegradability of LAS decreased with increasing the degree of oxidation. The WAO of LAS at $1600 \mathrm{mg} / \mathrm{L}$, temperatures ranging 180$240^{\circ} \mathrm{C}$ and pressures ranging from 3.05 to $6.55 \mathrm{MPa}$ produced by-products that included low molecular weight VFAs (volatile fatty acids) such as formic and acetic acids, sulfonated aromatics, and sulfate. For a reaction time of 120 minutes at $1.5 \mathrm{MPa} \mathrm{O}_{2}$ partial pressure, increasing the temperature gave an improvement in LAS removal from $79 \%$ to $100 \%$ and COD removal from $23 \%$ to $70 \%$. Increasing the pressure was found to have little impact on TOC and COD removal. In another study, a semi-batch WAO of LAS at temperatures of 453 and $473 \mathrm{~K}$ and total pressures of 2.8 and $3.3 \mathrm{MPa}$ with a reaction time of 40-390 minutes has been investigated [77]. In agreement with the results of a previous study, LAS was readily degraded to smaller molecules that did not behave as surfactants. TOC removal only reached 50\% because of the resistance of small organic acids to further oxidation [75].

\subsubsection{Sonochemical degradation of surfactants}

Vinodgopal [78] studied the ultrasound (363 kHz) induced degradation of nonylphenol ethoxylate. Ultrasonic degradation is a result of ultrasound-induced cavitations. Acoustic cavitation involves the formation, growth, and implosion of very small gas bubbles. The implosion of the bubbles results in near adiabatic heating of the gas and vapour inside the bubble. High local temperatures and pressures are referred to as hot spots. These conditions can result to the homolysis of water molecules to produce $\mathrm{H}^{\bullet}$ and ${ }^{\bullet} \mathrm{OH}$ radicals. The attack of the surfactant molecules by the radicals and thermal decomposition are the main pathways of degradation. The rates of degradation are dependent on the initial surfactant concentrations. The degradation of alkylphenol ethoxylates by ultrasound is dependent on the surfactant concentration being below the critical micelle concentration since micelles effectively shielded surfactant monomers from $\mathrm{H}^{\bullet}$ and $\bullet{ }^{\circ} \mathrm{OH}$ radicals [79].

\subsubsection{Foam fractionation of surfactants}

Foam fractionation is accomplished by sparging air to produce tiny bubbles that collect surfactant molecules as they rise to the top of the liquid and produce foam. The thin liquid film between the air bubbles is stabilized by the adsorbed surfactant. The liquid drains form this thin liquid film due to gravity [80]. Foam fractionation was used as a method for the treatment of sodium dodecylsulfate contaminated water and provided 90\% recovery [80]. Wungrattanasopon et al. [81] studied foam fractionation to remove tert-butylphenol by using sodium dodecylsulfate and confirmed Tharapiwattananon's results [80] of 90\% surfactant recovery.

\subsubsection{Electrochemically generated coagulant treatment} of surfactants

Electrochemically generated coagulants are formed by passing an electrical current through an iron or aluminum electrode (anode) that in turn releases $\mathrm{Al}^{3+}$ or $\mathrm{Fe}^{2+}$ as a result of electron consumption. Hydrogen gas forms at the cathode. Depending upon the $\mathrm{pH}$, aluminum oxide or iron oxide flocs form and float to 
the surface carrying the contaminants. The removal of nonylphenol ethoxylates with electrochemically generated aluminum and iron coagulants using aluminum and carbon steel electrodes with a current density of $10 \mathrm{~A} / \mathrm{m}^{2}$ was tested and it was found that the longer the ethoxylate chain, the more hydrophilic the NPEO, therefore, the less tendency to adsorb the flocs leading to lower removal rates [82]. Removal rates of NP4EO (4 EO groups) were between 40 and 80\% and for NP16EO (16 EO groups) 30 to $50 \%$.

\subsubsection{Fenton's treatment of surfactants}

The Fenton reaction is as follows:

$$
\mathrm{Fe}^{2+}+\mathrm{H}_{2} \mathrm{O}_{2} \longrightarrow \mathrm{Fe}^{3+}+\cdot \mathrm{OH}+\mathrm{OH}^{-}
$$

Generated hydroxyl radicals react with organic compounds and ultimately degrade them to carbon dioxide and water. The enhancement of the biodegradability of the NPEO with Fenton's treatment has been studied [83]. The COD of NPEO was $1000 \mathrm{mg} / \mathrm{L}$ used with $1000 \mathrm{mg} / \mathrm{L}$ hydrogen peroxide with an $\mathrm{H}_{2} \mathrm{O}_{2} / \mathrm{Fe}^{\mathrm{II}}$ equal to one. Batch aerobic experiments followed to test the biodegradability of the partially oxidized solution. It was concluded that Fenton's pretreatment reduced biodegradability with low hydrogen peroxide dosages and increased the biodegradability at higher $\mathrm{H}_{2} \mathrm{O}_{2}$ dosages. Lin et al. [84] found optimum operating conditions for treating $10 \mathrm{mg} / \mathrm{L}$ LAS to be $90 \mathrm{mg} / \mathrm{L}$ $\mathrm{FeSO}_{4}, 60 \mathrm{mg} / \mathrm{L}$ hydrogen peroxide with a reaction time of 50 minutes at $\mathrm{pH} 3$ to achieve greater than $95 \%$ removal. A first order kinetic model was fitted to the experimental results. Final treatment with a chemical coagulant was found to be highly beneficial in removing small iron oxide flocs formed during the reaction.

\subsubsection{Photo-Fenton treatment of surfactants}

Photo-Fenton treatment involves the irradiation of a solution containing hydrogen peroxide and ferric ions in order to degrade organic pollutants. The ferric ions act as a catalyst for the generation of hydroxyl radicals. A simplified photo-Fenton reaction is as follows:

$$
\begin{aligned}
& \mathrm{Fe}^{2+}+\mathrm{H}_{2} \mathrm{O}_{2} \longrightarrow \mathrm{Fe}^{3+}+\cdot{ }^{\circ} \mathrm{OH}+\mathrm{OH}^{-} \\
& \mathrm{Fe}^{3+}+\mathrm{H}_{2} \mathrm{O} \stackrel{\mathrm{h} v}{\longrightarrow} \mathrm{Fe}^{2+}+\mathrm{H}^{+}+\cdot \mathrm{OH}
\end{aligned}
$$

The photo-Fenton degradation of an alkylphenol ethoxylate (trade name Igepal CA 520) has been studied, in which a UV source of $365 \mathrm{~nm}$ was used. 60\% removal was achieved in six hours. Exposure to sunlight for 24 hours resulted in 90\% removal [85].

\subsubsection{Ozonation of surfactants}

First order reaction rates were observed with respect to NPEO concentration for degradation of NPnEOs $(n=4-$
30) in dilute solution [86]. A linear relationship was observed between first order rate constants and a number of ethoxylate groups. It was concluded that the high $\mathrm{O}_{3}$ concentrations do not enhance mineralization but low concentrations of $\mathrm{O}_{3}$ were sufficient to enhance the biodegradability of NPnEOs. The treatment efficiency of ozonation of sodium dodecylbenzene sulfonate (SDS) with varied $\mathrm{pH}$ and organic loading was investigated [87]. It was determined that alkaline conditions were favored since hydroxyl radicals were preferentially formed and were the main route of degradation. Ozonation was only able to partially remove SDS and COD but was concluded that ozonation followed by biodegradation might enhance the overall removal of COD.

\section{CONCLUSION}

Surfactants play a major role in our society. Ultimately, their usage in such large quantities means that their ultimate fate is highly important. It has been demonstrated that greater than $90 \%$ of many surfactants are removed in traditional biological wastewater treatment processes. The remainder can remain adsorbed to the biosolids at end up on agricultural land via reuse programs. Many methods of surfactant degradation and removal have been discussed in this study and it has been shown that the treatment of surfactant containing wastewaters at the source is a viable option. Degradation of linear alkylbenzene sulfonate at the source of pollution using Degussa P25 $\mathrm{TiO}_{2}$ combined with UV light $(365 \mathrm{~nm})$, hydrogen peroxide combined with UV light (254 nm) or UV light (254 nm) alone are potentially successful methods of reducing surfactant pollution.

\section{ACKNOWLEDGMENTS}

The support of Natural Sciences and Engineering Research Council of Canada (NSERC) is gratefully acknowledged.

\section{REFERENCES}

[1] T. C. J. Feitjtel, J. Struijs, and E. Matthijs, Environ. Toxicol. Chem. 18 (1999), 2645.

[2] D. A. Patterson, I. S. Metcalfe, F. Xiong, and A. G. Livingston, Ind. Eng. Chem. Res. 40 (2001), 5507.

[3] A. M. Neilsen, A. J. DeCarvalho, D. C. McAvoy, L. Kravetz, M. L. Cano, and D. L. Anderson, Environ. Toxicol. Chem. 21 (2002), 2606.

[4] D. C. McAvoy, S. D. Dyer, N. J. Fendinger, W. S. Eckhoff, D. L. Lawrence, and W. M. Begley, Environ. Toxicol. Chem. 17 (1998), 1705.

[5] L. Elsgaard, S. O. Petersen, and K. Debosz, Environ. Toxicol. Chem. 20 (2001), 1656.

[6] L. Elsgaard, S. O. Petersen, and K. Debosz, Environ. Toxicol. Chem. 20 (2001), 1664. 
[7] J. Hack, J. Chem. Technol. Biotechnol. 50 (1991), 379.

[8] T. Takasu, A. Iles, and K. Hasebe, Anal. Bioanal. Chem. 372 (2002), 554.

[9] G. Ying, B. Williams, and R. Kookana, Environ. Int. 28 (3) (2002), 215.

[10] E. R. Bennett and C. D. Metcalfe, Environ. Toxicol. Chem. 19 (2000), 784.

[11] E. Matthijs, M. S. Holt, A. Keiwiet, and G. B. J. Rus, Environ. Toxicol. Chem. 18 (11) (1999), 2634.

[12] L. N. Britton (CONDEA Vista Company, Austin, Texas), Technical Report on Surfactants and the Environment, http://www.cler.com/new/britton. html (accessed on Dec 24, 2003), JSD 1, 109-117 (1998).

[13] J. Tolls, M. P. Lehmann, and D. T. H. M. Sum, Environ. Toxicol. Chem. 19 (2000), 2394.

[14] W. Ding, S. Tzing, and J. Lo, Chemosphere 38 (1999), 2597.

[15] M. Holmstrup and P. H. Krogh, Environ. Toxicol. Chem. 20 (2001), 1673.

[16] B. Gejlsbjerg, C. Klinge, and T. Madsen, Environ. Toxicol. Chem. 20 (2001), 698.

[17] M. Holmstrup, P. H. Krogh, H. Lokke, W. De Wolf, S. Marshall, and K. Fox, Environ. Toxicol. Chem. 20 (2001), 1680.

[18] R. A. Kimerle and R. D. Swisher, Wat. Res. 11 (1977), 31.

[19] J. Jensen, H. Lokke, M. Holmstrup, P. H. Krogh, and L. Elsgaard, Environ. Toxicol. Chem. 20 (2001), 1690.

[20] G. K. Mortensen, H. Elsgaard, P. Ambus, E. S. Jensen, and C. Gron, J. Environ. Qual. 30 (2001), 1266.

[21] Z. Ou, L. Jia, H. Jin, A. Yediler, X. Jiang, A. Kettrup, and T. Sun, Chemosphere 38 (1999), 1985.

[22] M. Mosche and U. Meyer, Wat. Res. 36 (2002), 3253.

[23] R. A. Rudel, S. J. Melly, P. W. Geno, G. Sun, and J. G. Brody, Environ. Sci. Technol. 32 (1998), 861.

[24] D. C. McAvoy, A. J. DeCarvalho, A. M. Nielsen, and M. L. Cano, Environ. Toxicol. Chem. 21 (2002), 2623.

[25] M. J. La Guardia, R. C. Hale, E. Harvey, and T. M. Mainor, Environ. Sci. Technol. 35 (2001), 4798.

[26] W. Giger, E. Stephanou, and C. Schaffner, Chemosphere 10 (1981), 1253.

[27] S. Jobling and J. Sumpter, Aquat. Toxicol. 27 (1993), 361.

[28] S. R. Miles-Richardson, S. L. Pierens, K. M. Nichols, V. J. Kramer, E. M. Snyder, S. A. Snyder, J. A. Render, S. D. Fitzgerald, and J. P. Giesy, Environ. Res. Sec. A 80 (1999), S122.

[29] R. Ekelund, A. Bergman, A. Granmo, and M. Berggren Environ. Pollut. 64 (1990), 107.

[30] D. W. McLeese, V. Zitko, D. B. Sergeant, L. Burridge, and C. D. Metcalfe, Chemosphere 10 (1981), 723.
[31] D. Y. Shang, R. W. Macdonald, and M. G. Ikonomou, Environ. Sci. Technol. 33 (1999), 1366.

[32] P. L. Ferguson, C. R. Iden, and B. J. Brownawell, Environ. Sci. Technol. 35 (2001), 2428.

[33] R. J. Maguire, Environ. Toxicol. Chem. 34 (1999), 37.

[34] M. Hawrelak, E. Bennett, and C. Metcalfe, Chemosphere 39 (1999), 745.

[35] C. Verge, A. Moreno, J. Bravo, and J. L. Berna, Chemosphere 44 (2001), 1749.

[36] M. J. Rosen, F. Li, S. W. Morrall, and D. J. Versteeg, Environ. Sci. Technol. 35 (2001), 954.

[37] S. D. Dyer, D. T. Stanton, J. R. Lauth, and D. S. Cherry, Environ. Toxicol. Chem. 19 (2000), 608.

[38] C. D. Metcalfe, T. L. Metcalfe, Y. Kiparissis, B. G. Koenig, C. Khan, R. J. Hughes, T. R. Croley, R. E. March, and T. Potter, Environ. Toxicol. Chem. 20 (2001), 297.

[39] P. Spengler, W. Korner, and J. W. Metzger Environ. Toxicol. Chem. 20 (2001), 2133.

[40] W. Korner, P. Spengler, U. Bolz, W. Schuller, V. Hanf, and J. W. Metzger, Environ. Toxicol. Chem. 20 (2001), 2142.

[41] H. F. Bjerregaard, S. Staermose, and S. S. J. Vang, Toxicol. In Vitro 15 (2001), 531.

[42] J. Tolls and D. T. H. M. Sum, Environ. Toxicol. Chem. 18 (1999) 2689.

[43] E. Jorgensen and K. Christoffersen, Environ. Toxicol. Chem. 19 (2000), 904.

[44] E. Van De Plassche, J. H. M. De Bruijn, R. R. Stephenson, S. J. Marshall, T. C. J. Feijtel, and S. E. Belanger, Environ. Toxicol. Chem. 18 (1999), 2653.

[45] K. Fenner, C. Kooijman, M. Scheringer, and K. Hungerbuhler, Environ. Sci. Technol. 36 (2002), 1147.

[46] T. C. J. Feijtel, S. F. Webb, and E. Matthius, Food Chem. Toxicol. 38 (2000), S43.

[47] F. W. Jones and D. J. Westmoreland, Environ. Sci. Technol. 32 (1998), 2623.

[48] L. Rudling and P. Solyom, Wat. Res. 8 (1974), 115.

[49] B. Gejlsbjerg, T. Madsen, and T. T. Andersen, Chemosphere 50 (2003), 321.

[50] N. S. Battersby, A. J. Sherren, R. N. Bumpus, R. Eagle, and I. K. Molade, Chemosphere 45 (2001), 109.

[51] A. Marcomini, G. Pojana, C. Carrer, L. Cavalli, G. Cassani, and M. Lazzarin, Environ. Toxicol. Chem. 19 (2000), 535.

[52] C. A. Staples, C. G. Naylor, J. B. Williams, and W. E. Gledhill, Environ. Toxicol. Chem. 20 (2001), 2450.

[53] H. Feitkenhauer and U. Meyer, J. Chem. Technol. Biotechnol. 77 (2002), 979.

[54] C. C. Ang and A. S. Abdul, J. Hydrol. 138 (1992), 191.

[55] B. E. Rittmann, P. Tularak, K. Lee, T. W. Federle, N. R. Itrich, S. K. Kaiser, J. Shi, and D. C. McAvoy, Biodegradation 12 (2001), 31. 
[56] G. Boeije, H. Vanhooren, T. Verbrugge, and P. A. Vanrolleghem, Environ. Sci. Technol. 34 (2000), 4413.

[57] C. J. Krueger, K. M. Radakovich, T. E. Sawyer, L. B. Barber, R. L. Smith, and J. A. Field, Environ. Sci. Technol. 32 (1998), 3954.

[58] J. Doi, K. H. Marks, A. J. DeCarvalho, D. C. McAvoy, A. M. Nielsen, L. Kravetz, and M. L. Cano, Environ. Toxicol. Chem. 21 (2002), 2617.

[59] U. Branner, M. Mygind, and C. Jorgensen, Environ. Toxicol. Chem. 18 (1999), 1772.

[60] D. E. Sullivan, Wat. Res. 17 (1983), 1145.

[61] T. Aye, W. A. Anderson, and M. Mehrvar, J. Envion. Sci. Heal. A 38 (2003), 1903.

[62] A. Cuzzola, M. Bernini, and P. Salvadori, Appl. Catal. B-Environ. 36 (2002), 231.

[63] H. Hidaka, K. Ihara, Y. Fujita, S. Yamada, E. Pelizzetti, and N. Serpone, J. Photoch. Photobio. AChem. 42 (1988), 375.

[64] H. Hidaka, J. Zhao, E. Pelizzetti, and N. Serpone, J. Phys. Chem. 96 (1992), 2226.

[65] M. Mehrvar, W. A. Anderson, and M. Moo-Young, Int. J. Photoenergy 2 (2) (2000), 67.

[66] N. Nadarajah, J. Van Hamme, J. Pannu, A. Singh, and O. Ward, Appl. Microbiol. Biotechnol. 59 (2002), 540.

[67] C. S. Turchi, Ph.D. Thesis, North Carolina State University, 1990.

[68] R. Venkatadri and R. W. Peters, Hazard. Waste Hazard. Mater. 10 (1993), 107.

[69] K. B. Sherrard, P. J. Marriott, R. G. Amiet, and M. J. McCormick, Chemosphere 33 (1996), 1921.

[70] E. Pelizzetti, C. Minero, V. Maurino, A. Sciafani, H. Hidaka, and N. Serpone, Environ. Sci. Technol. 23 (1989), 1380.

[71] S. Horikoshi, N. Watanabe, H. Onishi, H. Hidaka, and N. Serpone, Appl. Catal. B-Environ. 37 (2002), 117.

[72] J. Saien, R. R. Ardjmand, and H. Iloukhani, Phys. Chem. Liq. 41, (2003), 519.
[73] A. E. Greenberg, L. S. Clesceri, and A. D. Eaton, in Standard Methods for the Examination of Water and Wastewater, 18th Edition, 1992, pp. 5-36.

[74] M. J. Dietrich, T. L. Randall, and P. J. Canney, Environ. Prog. 4 (1985), 171.

[75] D. Mantzavinos, D. M. P. Burrows, R. Willey, G. Lo Biundo, S. F. Zhang, A. G. Livingston, and I. S. Metcalfe, Wat. Res. 35 (2001), 3337.

[76] D. A. Patterson, I. S. Metcalfe, F. Xiong, and A. G. Livingston, J. Chem. Technol. Biotechnol. 77 (2002), 1039.

[77] D. Mantzavinos, D. M. P. Burrows, R. Willey, G. Lo Biundo, S. F. Zhang, A. G. Livingston, and I. S. Metcalfe, Ind. Eng. Chem. Res. 39 (2000), 3659.

[78] K. Vindogopal, M. Ashokkumar, and F. Grieser, J. Phys. Chem. B. 105 (2001), 3338.

[79] H. Destaillats, H. Hung, and M. R. Hoffmann, Environ. Sci. Technol. 34 (2000), 311.

[80] N. Tharapiwattananon, J. Scamehorn, S. Osuwan, J. Harwell, and K. Haller, Sep. Sci. Tech. 31 (1996), 1233.

[81] P. Wungrattanasopon, F. F. Scamehorn, S. Chavedej, C. Saiwan, and J. Harwell, Sep. Sci. Tech. 31 (1996), 1523.

[82] G. A. Ciorba, C. Radovan, I. Vlaicu, and S. Masu, J. Appl. Electrochem. 32 (2002), 561.

[83] M. Kitis, C. D. Adams, and G. T. Daigger, Wat. Res. 33 (1999), 2561.

[84] S. H. Lin, C. M. Lin, and H. G. Leu, Wat. Res. 33 (1999), 1735.

[85] N. Brand, G. Mailhot, and M. Bolte, Environ. Sci. Technol. 32 (1998), 2715.

[86] N. Narkis, B. Ben-David, and M. S. Rotel, Wat. Sci. Tech. 17 (1984), 1069.

[87] F. J. Beltran, J. F. Garcia-Araya, and P. M. Alvarez, Ind. Eng. Chem. Res. 39 (2000), 2214. 


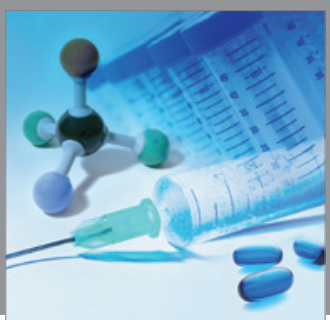

International Journal of

Medicinal Chemistry

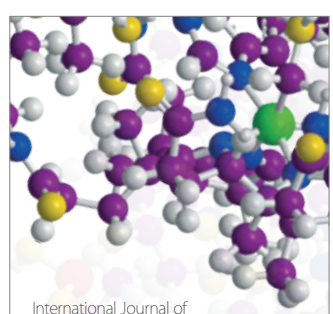

Carbohydrate Chemistry

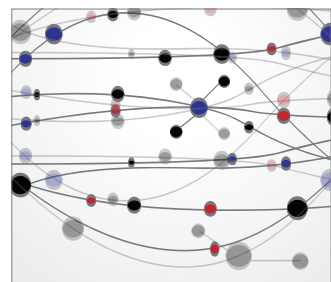

The Scientific World Journal
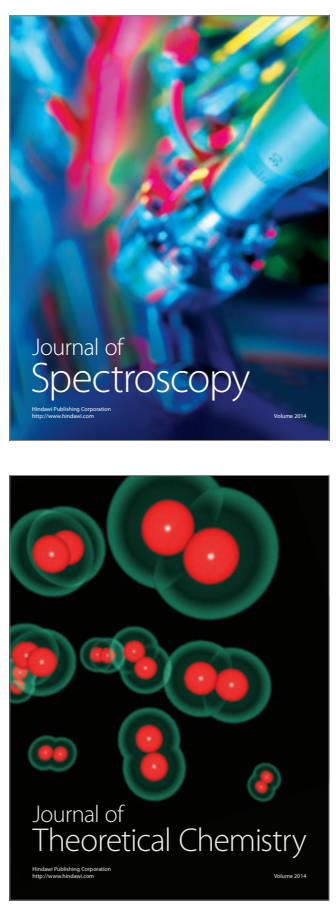
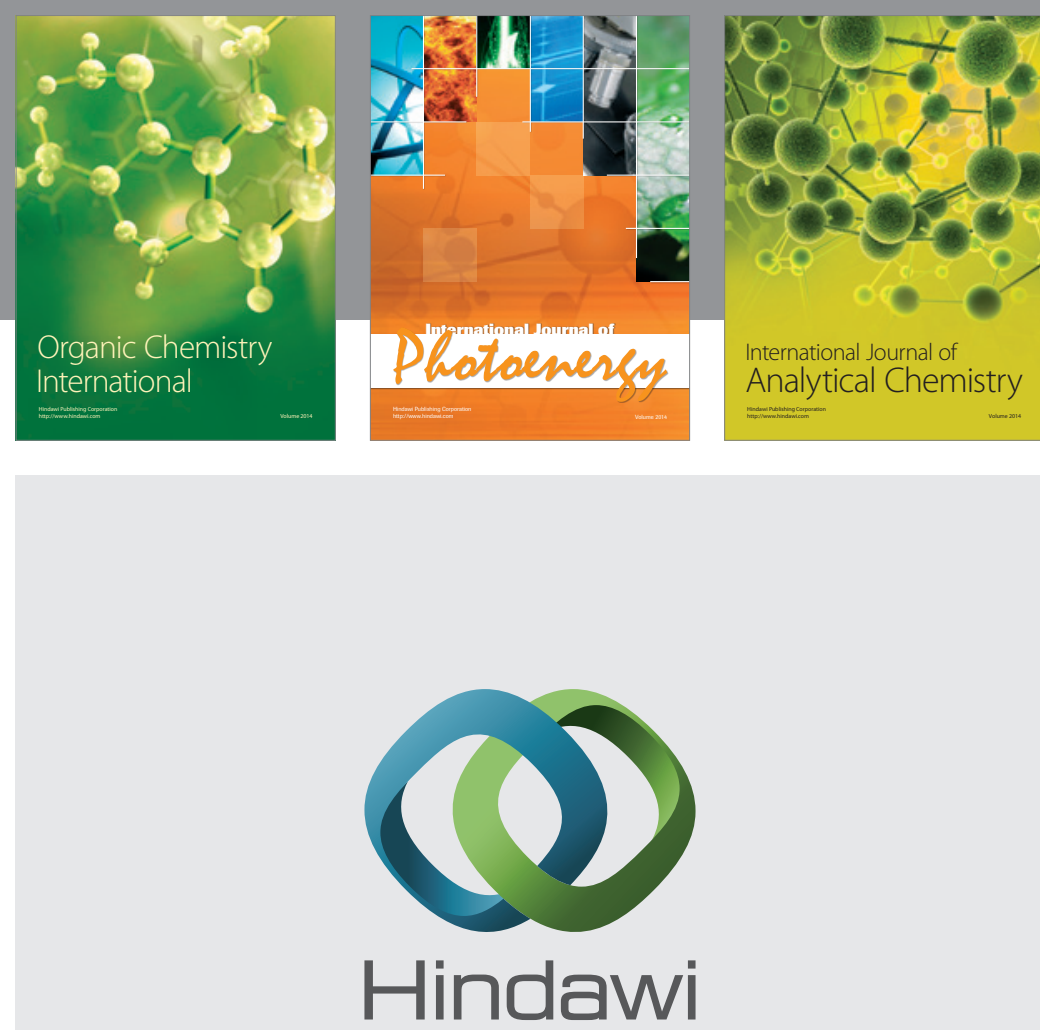

Submit your manuscripts at

http://www.hindawi.com
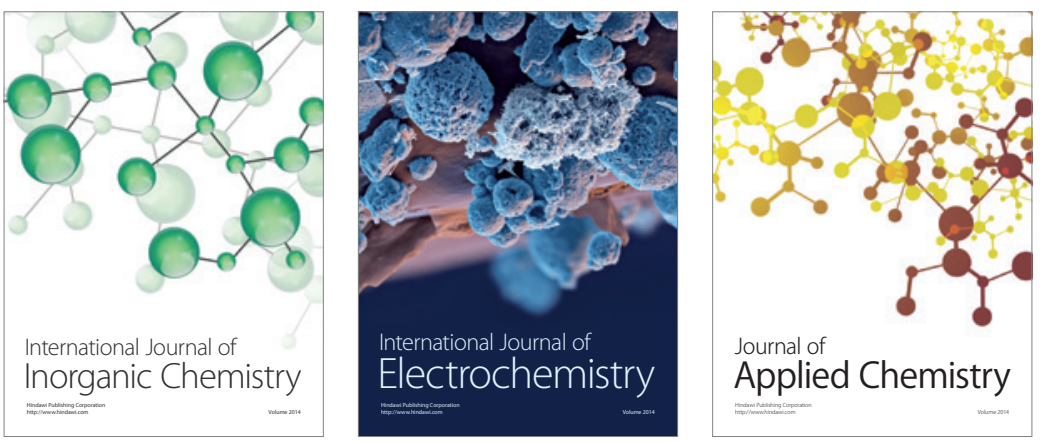

Journal of

Applied Chemistry
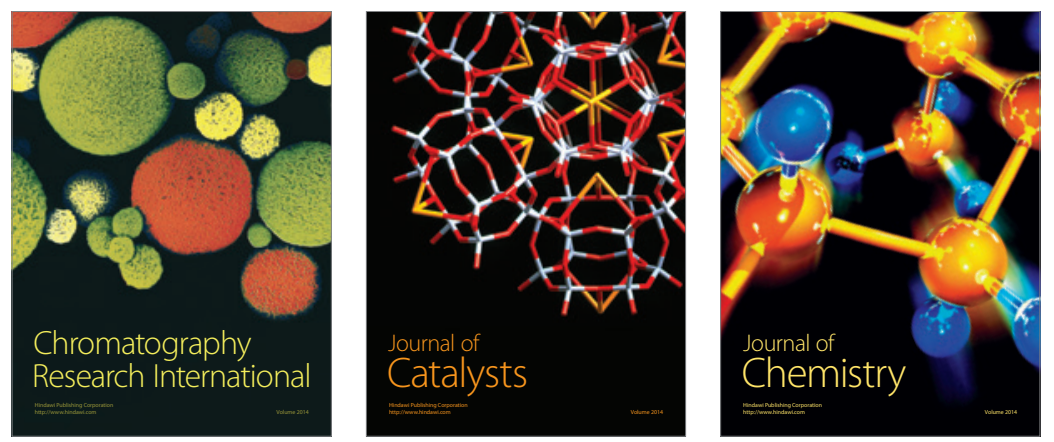
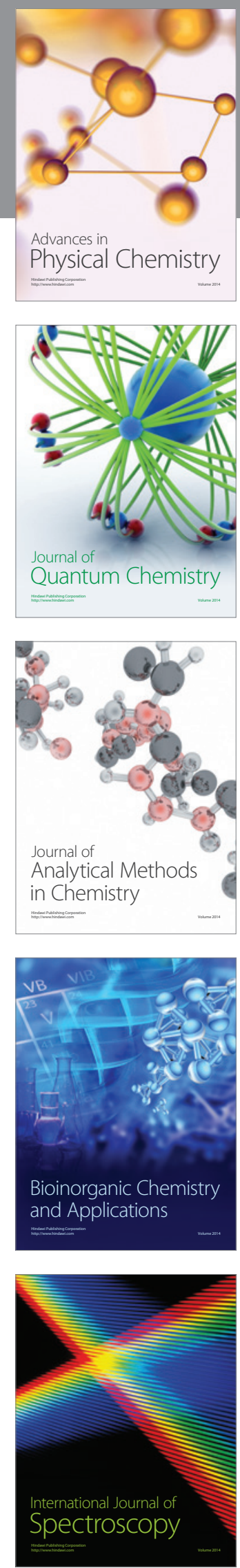